\title{
Apoptose e expressão de VP2 e GAPDH na infecção precoce pelo vírus da doença infecciosa da bursa de Fabricius em pintos SPF
}

\author{
[Apoptosis and expression of VP2 and GADPH in an experimental infectious bursal disease in SPF chicks] \\ J.J. Batista ${ }^{1}$, A.S. Martins ${ }^{1}$, L.Moro ${ }^{1}$, J.S. Resende ${ }^{2}$, N.R.S. Martins ${ }^{2}$, A.C. Vasconcelos ${ }^{1 *}$ \\ ${ }^{1}$ Instituto de Ciências Biológicas - UFMG \\ Caixa Postal 2486 \\ Belo Horizonte, $\mathrm{MG}$ \\ ${ }^{2}$ Escola de Veterinária - UFMG - Belo Horizonte, MG
}

\begin{abstract}
RESUMO
Vinte e nove pintos SPF de um dia foram inoculados com o vírus da doença infecciosa da bursa de Fabricius (VDIB) para avaliar a ocorrência precoce de apoptose e a expressão da proteína viral 2 (VP2) e da enzima gliceraldeído fosfato dehidrogenase (GAPDH). Os animais foram distribuídos em cinco grupos: 1-controle; e 2 a 5- com 24, 48, 72 e 96 horas pós-inoculação, respectivamente. Fragmentos da bursa de Fabricius foram colhidos para processamento histológico e extração de RNA. Lâminas coradas em HE e TUNEL (marcação in situ da fragmentação do genoma com transferase terminal de deoxinucleotídeo) foram utilizadas na morfometria do índice apoptótico. Amostras de mRNA foram testadas para a expressão dos genes VP2 e GAPDH utilizando-se transcrição reversa e RT-PCR. Utilizouse um kit SYBR GREEN PCR, e a reação foi desenvolvida em ABI Prism 7000 SDS. Os índices apoptóticos cresceram progressivamente indicando uma relação na atrofia bursal causada pelo VDIB. Paralelamente, os resultados da PCR em tempo real demonstraram queda da carga viral nas células linfóides da bursa nos diferentes intervalos de tempo do experimento. Esses resultados sugerem um papel protetor da apoptose na diminuição da replicação viral
\end{abstract}

Palavras-chave: apoptose, IBDV, bursa de Fabricius, RT-PCR

\begin{abstract}
Twenty-nine SPF 1-day-old chicks were inoculated with infectious bursal disease virus (IBDV) to evaluate early apoptosis and the expression of viral protein 2 (VP2) and glyceraldehyde-3-phosphate dehydrogenease (GAPDH). Five groups were formed: G1-control -and G2 to G5, - 24, 48, 72 and 96 hours post inoculation, respectively. Half of each BF was fixed and processed by routine techniques. To quantify apoptosis, 5um-thick sections were stained with HE and submitted to TUNEL (terminal transferase UDP nick end labeling) technique. $m R N A$ was extracted from pooled samples of 3 animals/group and used for the expression of VP2 and GADPH genes using the reverse transcription and real-time polymerase chain reaction (RT-PCR). A SYBR GREEN PCR kit was used and the reaction was carried out in an ABI Prism 7000 SDS. Apoptotic indexes progressively increased indicating a role of $I B D V$ in inducing hypotrophy of the BF. Also, it was showed that as long as apoptosis increased, viral protein expression decreased, which suggests that apoptosis plays a role as a defense mechanism against viral replication.
\end{abstract}

Keywords: apoptosis, IBDV, bursa of Fabricius, RT-PCR

Recebido em 23 de fevereiro de 2006

Aceito em 9 de fevereiro de 2007

* Autor para correspondência (corresponding author)

E-mail: anilton@icb.ufmg.br 


\section{INTRODUÇÃO}

A apoptose é a morte celular individual e ativa, caracterizada pela fragmentação nuclear e celular em corpos apoptóticos (Cohen, 1991). Ao contrário da necrose, não há liberação do conteúdo celular no interstício e, consequentemente, não há inflamação ao redor das células apoptóticas (Wyllie, 1981). Esse tipo de autodestruição celular pode ser induzido por estímulos fisiológicos e patológicos. Muitas infecções virais podem desencadear apoptose (Vasconcelos e Lam, 1994; Sarli et al., 1998; Moro et al., 2003).

A doença da bursa de Fabricius (DIB) é uma infecção viral aguda e altamente contagiosa que acomete aves jovens, e afeta particularmente os linfócitos $\mathrm{B}$ da bursa de Fabricius (BF), mas agride também outros órgãos linfóides como tonsilas cecais e baço (Tessari et al., 2001). Essa virose resulta na depleção linfocitária, atrofia da BF e imunossupressão, causando grandes perdas econômicas para a indústria avícola (Kibenge et al., 1988; Sharma et al., 2000). A imunossupressão se deve, em parte, ao fato do vírus da DIB (VDIB) induzir apoptose de linfócitos em galinhas (Vasconcelos e Lam, 1994; Vasconcelos e Lam, 1995; Lam, 1997; Tanimura e Sharma, 1997; Nieper et al., 1999). Ainda não se conhece como o VDIB desencadearia a ocorrência de apoptose.

Segundo Nieper et al. (1999), há uma correlação entre a replicação do VDIB e a ocorrência de apoptose na BF. O mecanismo indireto foi sugerido por Inoue et al. (1994), uma vez que a apoptose ocorria em células T do timo, enquanto o antígeno de VDIB era encontrado principalmente nas células $\mathrm{B}$ ou em células reticulares. Em secções seriadas da BF infectada pelo VDIB, Tanimura e Sharma (1997) observaram células apoptóticas não somente em folículos bursais antígeno-positivos, mas também em antígeno-negativos.

O genoma do VDIB consiste em dois segmentos de RNA de fita dupla, sendo um segmento menor (2800 bp) denominado B e outro maior (3400 bp) denominado A. As proteínas estruturais virais estão localizadas principalmente no segmento A (Muller et al., 1979; Steger et al., 1980). A estrutura viral é constituída de cinco proteínas: VP1, VP2, VP3, VP4 e VP5 (Becht et al., 1988).
A VP2 localiza-se na porção externa do capsídeo viral, relaciona-se à antigenicidade do vírus (Ito, 1990) e é indutora de apoptose (Fernandez-Arias et al., 1997).

A utilização e a otimização de técnicas mais sensíveis, tais como a RT-PCR, permitiram o estudo da expressão de alguns genes envolvidos na via de apoptose induzida pelo VDIB e a quantificação da carga viral. Os objetivos deste estudo foram: quantificar a apoptose 24, 48, 72 e 96h após a inoculação induzida pelo VDIB nas células da BF, determinar a expressão da VP2 como estimativa da carga viral às $24,48,72$ e 96h após a inoculação pelo VDIB e correlacionar a apoptose com a replicação viral, estimada pela expressão da VP2.

\section{MATERIAL E MÉTODOS}

Os ovos embrionados livres de patógenos específicos (SPF), obtidos da Granja Sadia (Uberlândia), foram incubados no setor de aves do DMVP-EV - UFMG. Após a eclosão, 29 pintos Leghorn (SPF) de um dia de idade foram distribuídos, ao acaso, em cinco grupos experimentais: grupo 1- controle com cinco aves e grupos 2, 3, 4 e 5 formados por seis aves cada, e que foram submetidos à eutanásia às $24,48,72$ e 96 horas da inoculação, respectivamente. Os animais foram inoculados com amostra viral tipificada (A-BH83) e titulada $\left(0,5 \times 10^{3} \mathrm{DLE}_{50} /\right.$ ave $)$.

À necropsia, fragmentos da BF foram colhidos para processamento histológico e para extração de RNA (fragmentos estocados à $-80^{\circ} \mathrm{C}$ ). Lâminas com secções de $5 \mu \mathrm{m}$ foram coradas em HE para determinação do índice apoptótico e preparados para a reação de TUNEL, que marca in situ as extremidades 3'-OH do DNA fragmentado no processo de apoptose. A fragmentação in situ do genoma foi detectada usando-se o Kit Oncor- ApopTag ${ }^{T M}$ in situ apoptosis detection kit ${ }^{1}$, seguindo as recomendações do fabricante: as secções foram incubadas com $20 \mu \mathrm{g} / \mathrm{ml}$ de proteinase $\mathrm{K}^{2}$, e a peroxidase endógena foi inativada com água oxigenada a $2 \%$ em metanol. Após a adição dos desoxinucleotídeos, as lâminas foram incubadas

${ }^{1}$ Oncor - Gaithersburg, EUA (S7100-KIT).

${ }^{2}$ SIGMA - São Paulo, Brasil. 
em câmara úmida a $37^{\circ} \mathrm{C}$ por $3 \mathrm{~h}$. A reação foi bloqueada com o tampão de parada, os cortes foram tratados com streptoavidina peroxidase, a revelação da reação foi feita com 3,3diaminobenzidina e a contracoloração com verde de metila.

A quantificação da apoptose foi feita em um número mínimo representativo de campos definido pela avaliação da evolução dos errospadrão de acordo com o aumento da amostragem (Sampaio, 1998; Moro et al., 2004). Determinouse o índice apoptótico $(\mathrm{IA}=$ somatório das células com morfologia de apoptose/ somatório das células totais $\mathrm{x} 100$ ) em HE a partir da contagem de células no número máximo obtido de campos tomados aleatoriamente. Os campos foram contados em objetiva planacromática de 40x. Desses, formaram-se amostras crescentes de campos de 5 em $5(5,10,15 \ldots$., etc) retirados aleatoriamente com reposição. Essas amostras foram caracterizadas por suas médias e respectivos erros padrões. Assim, o IA foi determinado em 10 campos/lâmina (calculados pelo erro-padrão) tomados aleatoriamente para cada animal. Na quantificação do IA, foram consideradas células em apoptose somente aquelas que apresentaram pelo menos três dos seguintes critérios morfológicos de inclusão (Vasconcelos, 2001): anoiquia - retração celular e perda de adesões entre células e membrana basal -, condensação do citoplasma e condensação nuclear - compactação da cromatina nuclear em massas densas uniformes, alinhadas no lado interno da membrana nuclear, inclusive com aspecto de crescentes -, e fragmentação nuclear - convolução e fragmentação da membrana nuclear, sem cariorrexe ou ruptura -, fragmentação celular - com formação dos corpos apoptóticos -, fagocitose dos corpos apoptóticos pelas células adjacentes ("canibalismo celular") e ausência de inflamação. O delineamento experimental foi inteiramente ao acaso, sendo os dados paramétricos e com distribuição normal analisados pela análise de variância para grupos independentes, adotando-se $\mathrm{P} \leq 0,05$. Para análise da variação entre os grupos, foi aplicado o teste de comparação múltipla de Newman-Keuls, adotando-se $\mathrm{P} \leq 0,001$.

Para a extração de RNA total, utilizou-se a técnica descrita por Chomczynski e Sacchi (1987). Amostras de 200mg de BF foram homogeneizadas em $0,5 \mathrm{ml}$ de solução D (4M isotiocianato de guanidina, $25 \mathrm{Mm}$ de citrato de sódio pH 7,0, $0.5 \%$ sarcosil, $0,1 \quad \mathrm{M} \quad 2$ mercaptoetanol). Adicionaram-se $0,1 \mathrm{ml}$ de acetato de sódio $2 \mathrm{M}, 0,5 \mathrm{ml}$ de fenol e $0,5 \mathrm{ml}$ de clorofórmio:álcool isoamílico (49:1). A suspensão foi resfriada em gelo por 15 minutos e centrifugada por 20 minutos a $10000 \mathrm{x} \mathrm{g} / 4^{\circ} \mathrm{C}$. À fase aquosa adicionaram-se $0,5 \mathrm{ml}$ de isopropanol, com armazenagem a $-20^{\circ} \mathrm{C} / 1 \mathrm{~h}$ e centrifugação a $10000 \mathrm{x} \mathrm{g} / 20 \mathrm{~min} / 4^{\circ} \mathrm{C}$. O pellet de RNA foi dissolvido em $0,3 \mathrm{ml}$ de solução $\mathrm{D}$ e precipitado com $0,3 \mathrm{ml}$ de isopropanol a $-20^{\circ} \mathrm{C}$. O precipitado foi centrifugado a $14000 \mathrm{~g} / 4^{\circ} \mathrm{C} / 10$ minutos e os pellets de RNA ressuspendidos em etanol a $75 \%$, secos a vácuo e diluídos em $100 \mu l$ de água DEPC $(0,5 \mathrm{ml}$ de pirocarbonato dissolvido em água ultra-pura - qsp 1 litro solução autoclavada). As concentrações das amostras de RNA foram determinadas pela leitura da densidade óptica (OD) em comprimento de onda de 260nm em espectrofotômetro GeneQuant e usadas para o estudo da expressão dos genes da VP2 e do GAPDH por meio da transcrição reversa e da técnica de PCR em tempo real. Os primers (Tab. 1) foram selecionados com base na análise das seqüências dos cDNAs das regiões VP2 do vírus e do GAPDH descritas no Gene Bank, obtidas por meio do programa Blastn (http://www.ncbi.nlm.nih.gov/blast/blast.cgi). A transcrição reversa foi realizada usando-se $2,0 \mu \mathrm{g}$ de RNA total, $1 \mu \mathrm{l}(1 \mathrm{pmol} / \mu \mathrm{l})$ dos primers reversos VP2 e GAPDH, $5 \mu \mathrm{l}$ de oligo dT $(50 \mathrm{pmol} / \mu \mathrm{l})$. A mistura foi incubada a $37^{\circ} \mathrm{C} / 10$ minutos. Após incubação, acrescentaram-se às amostras, colocadas em gelo, $2 \mu \mathrm{l}$ de tampão reação $10 \mathrm{x}, 2 \mu \mathrm{l}$ de dNTP $\operatorname{mix}(1,25 \mathrm{mM} / \mu \mathrm{l}), 2 \mu \mathrm{l}$ de DTT $0,1 \mathrm{M}, 2 \mu \mathrm{l}(20 \mathrm{U} / \mu \mathrm{l})$ de transcriptase reversa $^{3}$ (Invitrogen). As amostras foram incubadas a $41^{\circ} \mathrm{C} / 60$ minutos, colocadas em gelo e armazenadas $\mathrm{a}-20^{\circ} \mathrm{C}$.

Após a purificação, foi feito um gel de poliacrilamida com $2 \mu$ l (200ng) de marcador $50 \mathrm{pb}$ DNA ladder e $15 \mu 1(\approx 300$ ng para VP2 e $\approx 120$ ng para GAPDH) dos fragmentos para confirmação de sua integridade e pureza. Para a reação de PCR em tempo real, foi utilizado o kit SYBR GREEN PCR core reagents ${ }^{4}$. A reação consistiu-se em: $6,65 \mu 1 \mathrm{de}$ água para PCR (SF); 1,5 $\mu 1$ de tampão (10x SYBR Green PCR buffer); $1,2 \mu 1$ de dNTP mix $(200 \mu \mathrm{M}$

\footnotetext{
${ }^{3}$ Invitrogen - São Paulo, Brasil

${ }^{4}$ Applied Biosystems (4304886) - Warrington, UK
} 
cada); $1,5 \mu 1$ de $\mathrm{MgCl}_{2}(25 \mathrm{mM}) ; 3 \mu 1$ de VP2 primer mix (senso e anti-senso - 1,5pmol cada) e $3 \mu \mathrm{lde}$ GAPDH primer mix (senso e anti-senso - 1,5pmol cada); $0,15 \mu \mathrm{l}(5 \mathrm{U} / \mu \mathrm{l})$ de enzima AmpliTaq GoldTM e $1 \mu 1$ de cDNA da reação de transcrição reversa. A reação em tempo real foi realizada no aparelho ABI Prism 7000 SDS. Como controle positivo e para posterior quantificação dos resultados, uma curva-padrão dos amplicons de VP2 e GAPDH purificados foi construída a partir de diluições seriais. Para confirmação do tamanho dos fragmentos amplificados por PCR em tempo real, foi realizada uma curva de dissociação como parte do programa estabelecido no ABI Prism 7000 $S D S$; os fragmentos amplificados também foram posteriormente visualizados por meio de eletroforese em gel de poliacrilamida corado com nitrato de prata.

Tabela 1. Seqüências de 21nt escolhidas como primers $^{1}$ para amplificação dos genes VP2 e GAPDH

\begin{tabular}{lc}
\hline Primer & Seqüência de nucleotídeos \\
\hline VP2 & GAC GAT CCA CGG TGG CAA CTA (Senso) \\
& GAC CGT AAC GAC AGA TCC TGT (Anti-senso) \\
GAPDH & CTA AGC GTG TTA TCA TCT CAG (Senso) \\
& GAC TTG TCA TAT TTC TCA TGG (Anti-senso)
\end{tabular}

${ }^{\mathrm{T}}$ Invitrogen Life Techinologies

\section{RESULTADOS E DISCUSSÃO}

A BF dos pintos inoculados mostrou depleção progressiva dos folículos linfóides aliada ao incremento dos índices apoptóticos (Fig. 1A-E). Os critérios morfológicos foram validados pela técnica de TUNEL (Fig. 1F e 1G), que mostrou grumos acastanhados nos núcleos de linfócitos com fragmentação do genoma. $\mathrm{O}$ índice apoptótico foi maior nos infectados $(\mathrm{P} \leq 0,001)$ que no controle, e cresceu progressivamente nos diversos intervalos de tempo, exceto entre $24 \mathrm{e}$ 48 horas (Fig. 2). Dessa forma, a apoptose é um evento precoce na infecção pelo VDIB, estando presente logo nos primeiros momentos após a inoculação.

A Tab. 1 mostra a seqüência dos primers selecionados para a RT PCR em tempo real. Os primers de $21 \mathrm{nt}$ foram selecionados levando-se em consideração regiões com conteúdo satisfatório de GC. As seqüências escolhidas para confecção dos oligonucleotídeos iniciadores foram pesquisadas no Blastn para garantir a exclusão de regiões homólogas com os alvos pesquisados. Essa estratégia foi fundamental para o sucesso de amplificação pela PCR convencional, bem como pela PCR em tempo real neste trabalho. A utilização da região de junção para splicing, contendo um intron, na seleção dos primers reduz a possibilidade de influência de possíveis contaminações por DNA genômico das preparações de RNA total durante a amplificação (Ausubel et al., 1995). A contaminação por DNA genômico poderia interferir na etapa de PCR, posterior à transcrição reversa, levando a uma falsa interpretação da expressão do mRNA reverso-transcrito. Portanto, a estratégia utilizada reduz a possibilidade de amplificação inespecífica de DNA genômico e isso permitiu a obtenção de fragmentos puros e específicos para os genes escolhidos.

As curvas-padrão para cada gene alvo foram obtidas (VP2 na Fig. 3) pela reação da PCR em tempo real com o programa ABI PRISM 7000 $S D S$. Os fragmentos amplificados em triplicata a partir do cDNA de amostras de BF apresentaram a clássica curva logarítmica com um $\mathrm{Ct}$ (total de ciclos) em torno de 17 ciclos. Além disso, o resultado da curva de dissociação dessas amostras representada no detalhe da Fig. 4 confirma a pureza, a qualidade, o tamanho e a especificidade dos fragmentos amplificados pela PCR em tempo real. A proteína viral VP2 apresentou um pico de expressão 24 horas após a inoculação viral. A ocorrência de apoptose aumenta enquanto a expressão da proteína viral VP2 diminui, sugerindo que a apoptose tenha um papel como mecanismo de defesa contra a replicação viral. Essas evidências deverão ser mais exploradas em estudos futuros. 

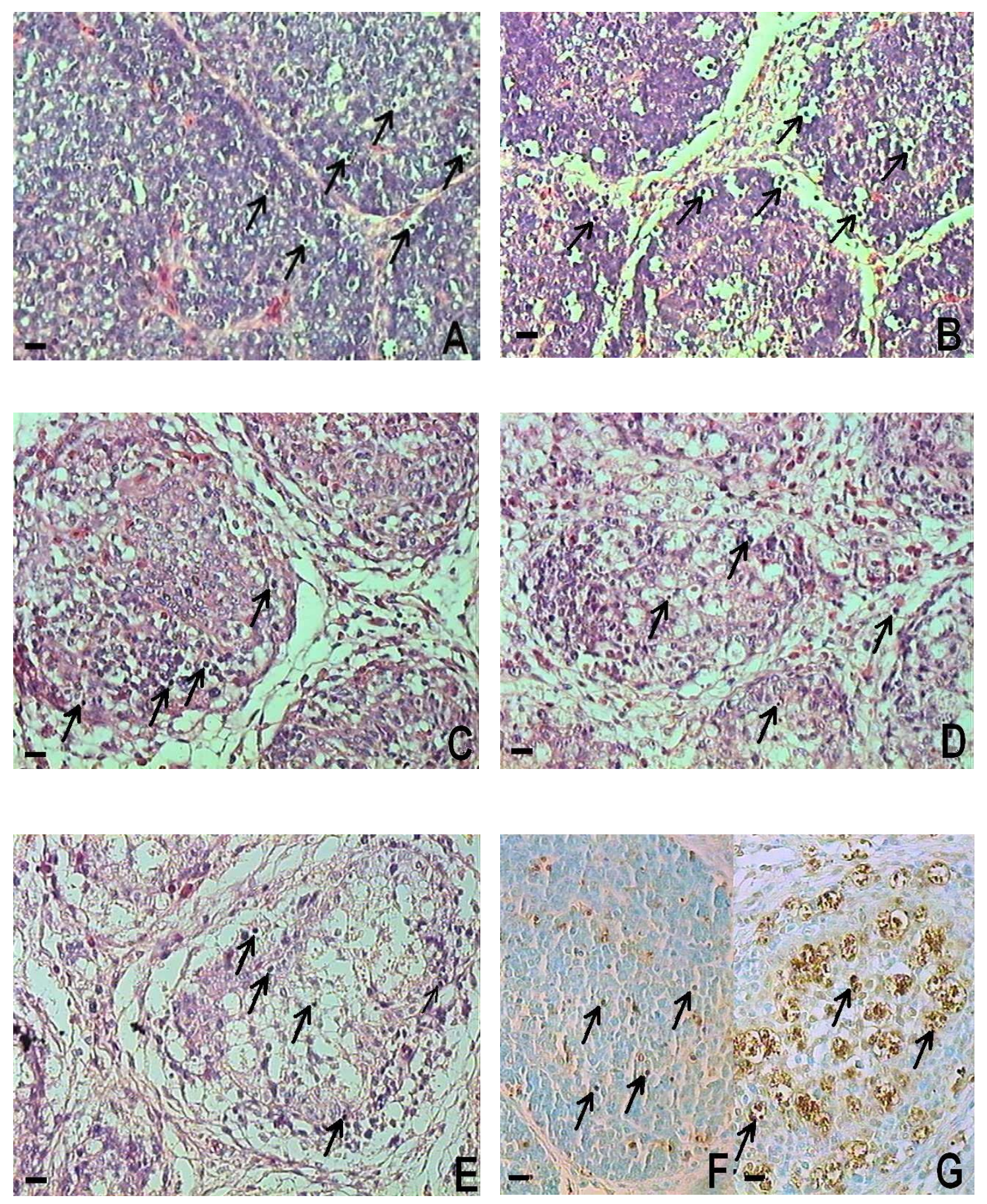

Figura 1. Bursa de Fabricius mostrando células em apoptose (setas). (A) animal controle; (B) 24 horas PI; (C) 48 horas PI; (D) 72 horas PI; (E) 96 horas PI; (F) BF de animal controle.; (G) BF 96 horas PI; (Barra = $10 \mu \mathrm{m}$ ). Coloração: HE (A, B, C, D e E) e TUNEL (F e G). PI= pós-inoculação. 


\section{Batista et al.}

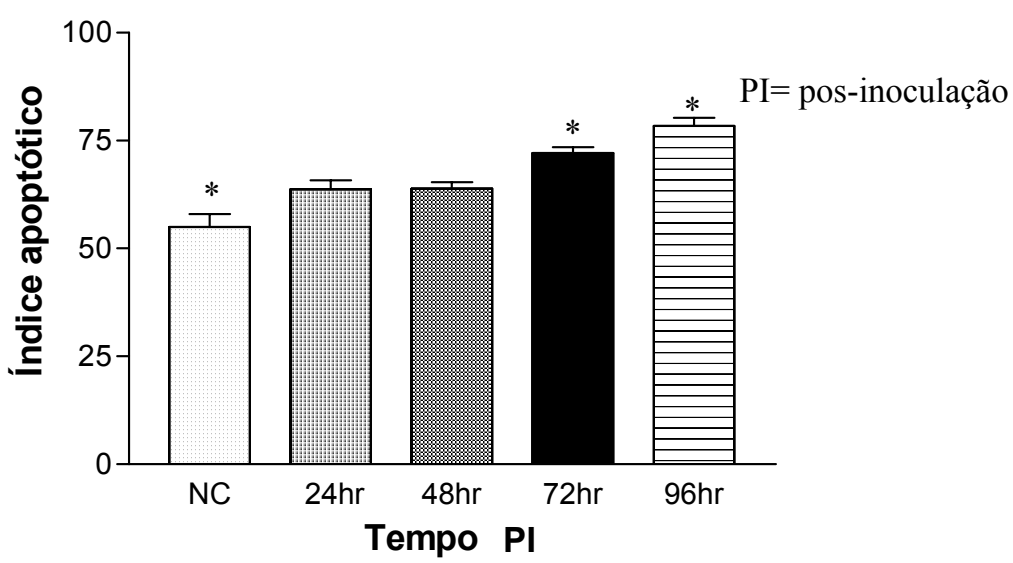

Figura 2. Crescimento progressivo do índice apoptótico. O asterisco indica os grupos que apresentaram diferenças estatísticas entre tempos.

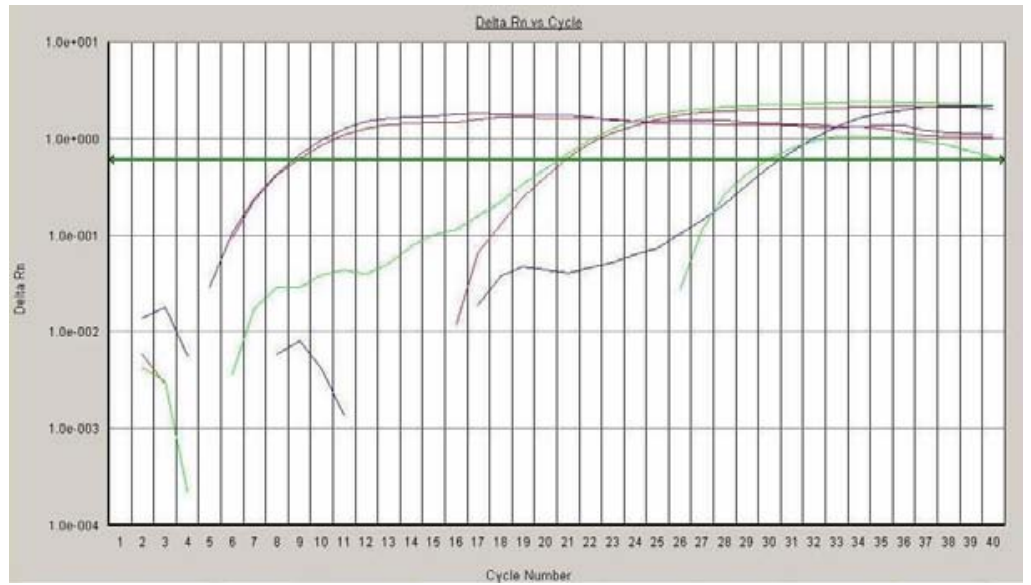

Figura 3. Quantificação da expressão da VP2 pela PCR em tempo real. A curva de calibração contém três curvas de amplificação refletindo diferentes quantidades iniciais de cDNA para VP2 do vírus, variando de 1 ng a $1 \times 10^{-6} \mathrm{ng}$.

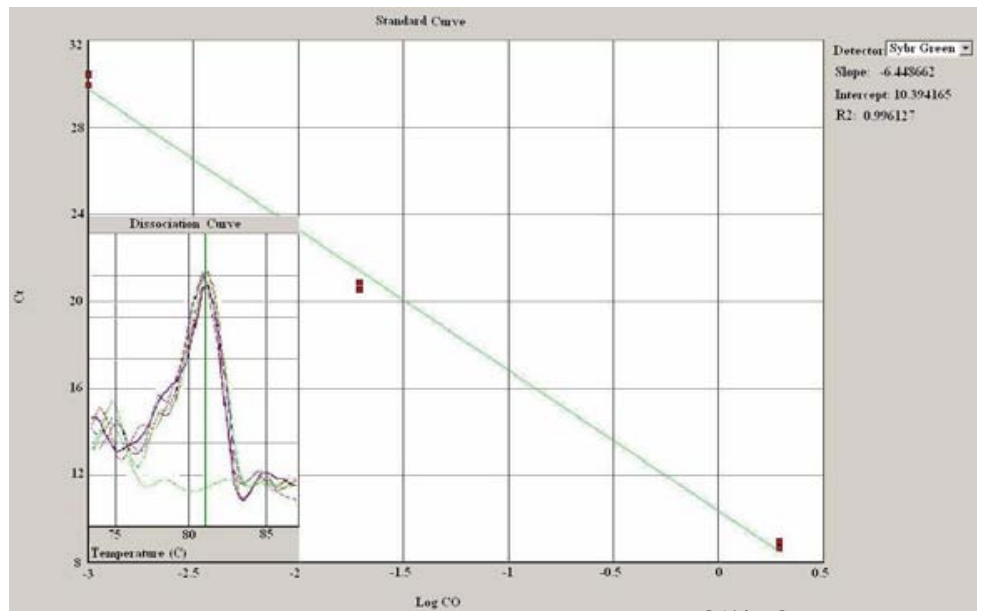

Figura 4. A eficácia da RTPCR (E) foi $100 \%$ obtida pela equação $E=10^{[-1 / \text { slope }]}$. A inclinação e a alta linearidade $\left(r^{2}=0.9961\right)$ são demonstradas pelos numerais ao lado direito da curva de calibração. A curva de dissociação apresentada no detalhe abaixo e à esquerda demonstra as temperaturas de fusão e pureza dos fragmentos gerados neste ensaio. 
Os amplicons para GAPDH e VP2 obtidos após eletroeluição dos fragmentos de PCR convencional foram utilizados para a construção das curvas apresentadas nas Fig. 5 e 6 . Os resultados da curva padrão, neste trabalho, demonstraram uma boa sensibilidade e reprodutibilidade da técnica. Os resultados das triplicatas foram altamente fiéis. Pode-se observar nessas figuras que o $\mathrm{Ct}$ foi perfeitamente mantido, logaritmicamente, com as diluições dos padrões GAPDH e VP2. Na Fig. 5 mostra-se a expressão da GAPDH, que inicialmente foi utilizada como um normalizador da reação. $\mathrm{Na}$ Fig. 6, mostra-se a expressão da proteína externa do capsídeo viral relacionada à antigenicidade do vírus (VP2) nos diferentes tempos após a inoculação. Houve maior expressão de VP2 em 24 horas após a inoculação do vírus com queda nos períodos subseqüentes. A diminuição da expressão da proteína VP2 pelo vírus em replicação parece estar relacionada ao aumento do IA. De fato, especula-se que os mecanismos associados à degradação do genoma na apoptose - como a ativação das endonucleases - poderiam também agir no sentido de suprimir ou inibir a replicação viral nas células linfocitárias da BF. O aumento do número de células em apoptose seria um mecanismo de proteção contra a replicação viral, já que o vírus necessita de células hospedeiras ativas para copiar o seu material genético. Assim, faz sentido que as células infectadas abortem a replicação viral pela ativação da morte celular programada. Esses achados necessitam, no entanto, ser mais explorados e confirmados em estudos futuros. Os resultados deste trabalho demonstram, pela primeira vez, a quantificação absoluta da expressão de VP2 por RT-PCR em tempo real.

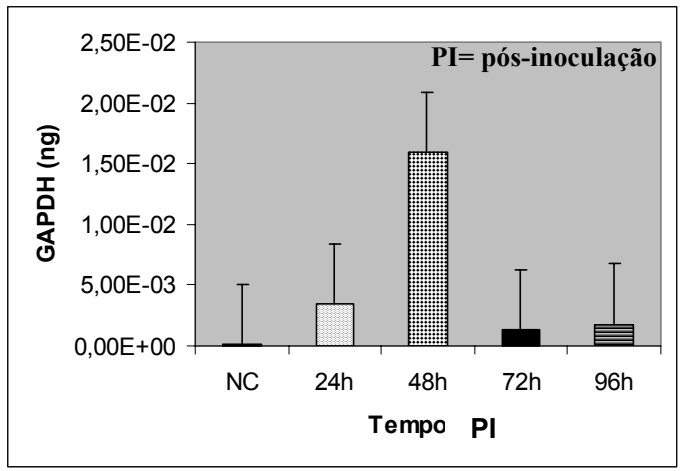

Figura. 5. Expressão da GAPDH, utilizada como um normalizador da reação. Observar que GAPDH mostrou uma expressão muito variada entre os grupos, indicando que sua expressão é influenciada pela replicação viral.

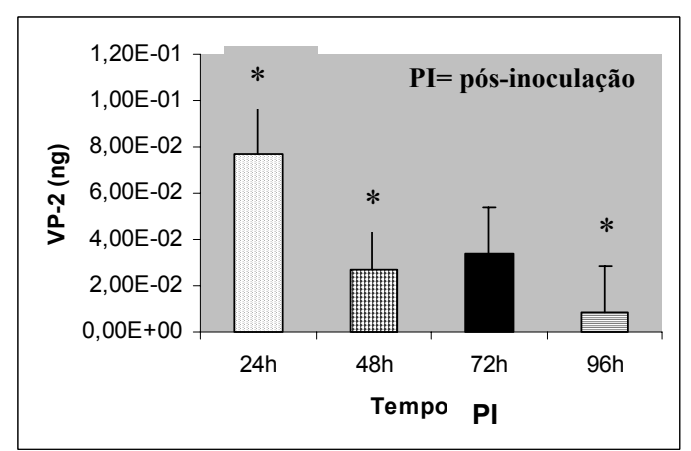

Figura 6. Expressão da VP2 do VDIB, utilizada como parâmetro para a quantificação da carga viral. $\mathrm{O}$ asterisco indica os grupos que mostraram diferenças significativas entre tempos.

\section{CONCLUSÕES}

A apoptose é um evento precoce na infecção com o vírus da DIB, já presente nos primeiros momentos após a inoculação sendo, portanto, mais que um simples mecanismo para a imunossupressão e atrofia bursal na DIB tardia. A demonstração da queda na carga viral nas células linfóides da bursa paralelamente ao aumento da apoptose nos diferentes intervalos de tempo após a inoculação do vírus sugere um papel protetor da apoptose na diminuição da replicação viral.

\section{REFERÊNCIAS BIBLIOGRÁFICAS}

AUSUBEL, F. A. Current protocols in molecular biology. v.2, New York: John Wiley and Sons, 1995.

BECHT, H.; MULlER, H.; MULLER, H.K. Comparative studies on structural and antigenic properties of two serotypes of infectious bursal disease virus. J. Gen. Virol., v.69, p.631-640, 1988.

CHOMCZYNSKI, P.; SACCHI, N. Single step method of RNA isolation by acid guanidinium thiocyanate-phenol-chloroform extraction. Anal. Biochem., v.162, p.156-159, 1987.

COHEN, J.J. Programmed cell death in immune system. Adv. Immunol., v.50, p.55-58, 1991.

FERNANDEZ-ARIAS, A.; MARTINEZ, S.; RODRIGUEZ, J.F. The major antigenic protein of infectious bursal disease virus, VP2, is an apoptotic inducer. J. Virol., v.71, p.8014-8018, 1997. 


\section{Batista et al.}

INOUE, M.; FUKUDA, M.; MIYANC, K. Thymics lesions in chicken infected with infectious bursal disease virus. Avian Dis., v.38. p. 839-846, 1994.

ITO, N.M.K. Infectious bursal disease: A case report. Bras. J. Vet. Res. Sci., v.27, p.99-110, 1990.

KIBENGE, F.S.B.; DHILLON, A.S.; RUSSELL, R.G. Biochemistry and immunology of infection bursal disease virus. J. Gen. Virol., v.69, p.17571775,1988

LAM, K.M. Morphological evidence of apoptosis in chickens infected with infectious bursal disease virus. J. Comp. Pathol. v.116, p.367-77, 1997.

MORO, L.; MARTINS, A.S.; ALVES, C. M. et al. Apoptosis in canine distemper. Arch. Virol., v.148, p.153-164, 2003.

MORO, L.; VASCONCELOS, A.C.; SANTOS, F.G.A. et al. Determination of the minimal representative number of microscopic fields to quantify apoptosis in canine lymph nodes. Arq. Bras. Med. Vet. Zootec., v.56, p.408-410, 2004.

MULLER, H.; SCHOLTISSEK, C.; BECHT, H. Genome of infectious bursal disease virus consists of two segments of double-strand RNA. J. Virol., v.31, p.584-589, 1979.

MULLIS, K.B.; FALOONA, F.A. Specific synthesis of DNA in vitro via a polymerasecatalyzed chain reaction. In: WU, R. (Ed). Methods in enzymology, San Diego: Academic, 1987. v.155, p.335-350.

NIEPER,H.; TEIFKE, J.P.; JUNGMANN, A. et al. Infected and apoptotic cells in the IBDV-infected bursa of Fabricius by double-labeling techniques. Avian Pathol., v.28, p.279-285, 1999.

SAMPAIO, I.B.M. Estatística aplicada à experimentação animal. Belo Horizonte: Fundação de Ensino e Pesquisa em Medicina Veterinária e Zootecnia, 1998. 221p.
SHARMA, J.M.; KIM, I.J.; RAUTENSCHLEIN, S. et al. Infectious bursal disease virus of chicken: pathogenesis and immunosuppression. Dev. Comp. Immunol., v.24, p.223-235, 2000.

STEGER, D.; MULLER, H.; RIESNER, D. Helixcore transitions in double-strength viral RNA: Fine resolution melting and ionic-strength dependence. Biochim. Biophys. Acta, v.606, p.274-285, 1980.

TANIMURA, N.; SHARMA, J. M. Appearance of $\mathrm{T}$ cells in the bursa of Fabricius and cecal tonsils during acute phase of infectious bursal disease virus infection in chickens. Avian Dis., v.41, p.638-645, 1997.

TESSARI, E.N.C.; CASTRO, A.G.M.; CARDOSO, A.L.S.P. et al. Ocorrência da doença de Gumboro em aves de postura causadas por cepas hipervirulentas. Arq. Int. Biol., v.68, p.115$117,2001$.

VASCONCELOS, A.C. Métodos aplicados ao estudo da Apoptose. Belo Horizonte: Instituto de Ciências Biológicas, UFMG, 2001. 17p.

VASCONCELOS, A.C.; LAM, K.M. Apoptosis in chicken embryos induced by the infectious bursal disease virus. J. Comp. Pathol., v.112, p.327-338, 1995.

VASCONCELOS, A.C.; LAM, K.M. Apoptosis induced by the infectious bursal disease virus. $J$. Gen. Virol., v.75, p.1803-1806, 1994.

WYLLIE, A. H. Cell death: A new classification separating apoptosis from necrosis. In: BOWEN, I.D.; LOCKSHIN, R.A. (Eds). Cell death in biology and pathology. New York: Chapman \& Hall, 1981. p.9-34. 